Prace Filologiczne. Literaturoznawstwo 11(14) 2021

ISSN 2084-6045

e-ISSN 2658-2503

Creative Commons: Uznanie autorstwa 3.0 PL (CC BY)

DOI: $10.32798 /$ pflit.624

\title{
ROLA FIGURY RETORYCZNEJ \\ W BUDOWANIU MODELU PERIODYZACJI \\ I WYZNACZANIU CEZUR - \\ PRZYKŁAD ZASTOSOWANIA SYLLEPSIS \\ W POEZJI POLSKIEJ OD ŚREDNIOWIECZA DO OŚWIECENIA
}

The Role of a Rhetorical Figure in Formulating a Model of Periodization and Establishing Time Marks. The Employment of Syllepsis in Polish Poetry

From the Middle Ages to the Enlightenment

\author{
ALEKSANDRA SIERMIŃSKA \\ Uniwersytet Warszawski, Polska \\ E-mail: a.iga.makowska@gmail.com \\ https://orcid.org/0000-0003-2198-4339
}

\begin{abstract}
Periodization and establishing time marks are generally associated with setting dates for the beginning and end of an era. Yet, it should be predominantly a rearrangement of a model of reality based on multidimensional analysis of the studied field. A diachronic approach to examine how the shift in priorities changes in consecutive eras is possible by means of reviewing the components of the text structure such as rhetorical figures. The author of this article delivers such a review employing syllepsis as an example of such a component. This particular rhetorical figure disappears from medieval texts, reappears in the Renaissance along with the works of classics' inspirations, then plays a crucial role in Baroque poetry, and finally vanishes almost entirely in the Age of Enlightenment.
\end{abstract}

Keywords: time marks, periodization, figures of speech, syllepsis, Middle Ages, Renaissance, Baroque, Enlightenment

\section{Streszczenie}

Wyznaczanie cezur i periodyzacja są kojarzone ze wskazywaniem granicznych dat epoki. Tymczasem powinno to być przede wszystkim rekonstruowanie modelu rzeczywistości opartego na wielowymiarowej analizie. Diachroniczne prześledzenie zmian akcentów w następujących 
po sobie epokach jest możliwe między innymi dzięki badaniu elementów konstrukcji tekstu, takich jak figury retoryczne. Dokonuję takiego przeglądu na przykładzie figury syllepsis, która po nieobecności w tekstach średniowiecznych, powraca w renesansie wraz z inspiracjami utworami klasyków, aby następnie odegrać istotną rolę w poezji baroku i ponownie niemalże zaniknąć w oświeceniu.

Słowa kluczowe: cezury, periodyzacja, figury retoryczne, syllepsis, średniowiecze, renesans, barok, oświecenie

Periodyzacja porządkuje chronologię wydarzeń, dotyczy więc czasu. Ze względu na zasięg wpływu uwzględnianych przez nią zjawisk pozostaje zarazem kategorią silnie zależną od przestrzeni. W celu zakreślenia granic rzeczywistości historycznoliterackiej jest zatem niezbędne zidentyfikowanie materiału określonego na obu płaszczyznach, na którym to dokonamy operacji wyznaczenia cech dystynktywnych epoki. Michael Titzmann, niemiecki teoretyk literatury, w pracy Probleme des Epochenbegriffs in der Literaturgeschichtsschreibung, definiuje epokę jako kontinuum czasu chronologicznego, w którym elementy pewnej klasy (np. określonego zbioru gatunkowego tekstów) w odniesieniu do pewnego zbioru kryteriów wykazują względną niezmienność. Badacz wskazuje zarazem na konieczność wyboru reprezentatywnego korpusu tekstów, który umożliwia prześledzenie interesujących nas zjawisk na podstawie dobranych kryteriów ${ }^{1}$.

Hipotetycznie, badany przez historyka literatury materiał mógłby zostać wybrany losowo ze zbioru utworów danego okresu, jednakże ze względu na wymóg reprezentatywności Titzmann określa ten sposób jako metodologicznie ryzykowny. Lepiej skonstruować miarodajne kryteria, które pozwolą na bardziej precyzyjne uchwycenie istotnych kwestii związanych $\mathrm{z}$ daną epoką.

Kryterium ograniczającym zakres badanego materiału może być występujący w dziełach wątek tematyczny (motyw bohaterskiej śmierci, niespełnionej miłości, egzystencjalnego buntu itp.). W ten sposób możliwe jest śledzenie zamkniętego zbioru podobnie zbudowanych utworów literackich przez przyglądanie się sposobowi odwzorowania w nich podobnych myśli. Daje to pewien stopień porównywalności, pozwalający na identyfikowanie schematów rozwojowych i obserwowanie przełomowych momentów w ich chronologicznym przebiegu. Granicę epok wyznaczałyby zasadnicze przekształcenia dotyczące powtarzalnych ujęć tego samego wątku i pewna masa przełomowa w postaci nowych wzorców anonsujących już kolejną epokę.

${ }^{1}$ M. Titzmann, Probleme des Epochenbegriffs in der Literaturgeschichtsschreibung, Konstanz 1967, s. 99-108. 
Praca nad periodyzacją i cezurami jest zatem pracą nad modelem, polegającą na zidentyfikowaniu reguł konceptualizacji tekstów przynależnych do następujących po sobie okresów historycznoliterackich. Do rozpoznawania tych reguł niezbędne są jasne kryteria pozwalające na wyłonienie korpusu dzieł zawierających określone elementy i zestawianie ich ze sobą.

Im łatwiejsze do zidentyfikowania elementy tekstu zostaną użyte jako kryteria doboru analizowanego materiału, tym trafniejsze będzie ich jakościowe porównywanie. Weryfikowalność występowania określonych przez kryteria zjawisk pozwala również na uwzględnienie ilościowych metod badania tekstu. Tylko wówczas, kiedy możemy precyzyjnie wyszczególnić, czy dane zjawisko występuje w utworach, czy nie, jesteśmy w stanie mówić o jego policzalności.

W związku z tym jako ciekawą, a dotychczas niewyzyskaną w pełni, podstawę periodyzacji Titzmann proponuje historykom literatury wykorzystanie figur retorycznych. Figura retoryczna może być opisana przez zestaw łatwych do zinterpretowania cech, pozwalających na dość dokładne stwierdzenie, czy mamy do czynienia z tą, a nie inną kategorią. Definiując figurę retoryczną, określamy niezależną od chronologii, stabilną strukturę pojęciową, którą można przykładać do utworów „wstecz”, co pozwala zarówno na gromadzenie danych ilościowych, jak i na jakościowe porównywanie funkcjonowania tej samej figury w zmieniającym się kontekście historycznym².

Badanie historii literatury przez pryzmat figur retorycznych wydaje się podejściem nowatorskim. Jak wskazuje Titzmann,

[...] wszystkie dotychczasowe historie literatury to raczej narracyjne [...] lub deskryptywne [...] historie zdarzeń; nie istnieje dotychczas taka historia struktur literatury, jaką posiada historiografia w ścisłym znaczeniu. Chodziłoby w niej nie tyle o substytucję, lecz o komplementarność; sama historia zdarzeń jako typ jest niezbędna, aczkolwiek nie odnosi się do każdego jej produktu ${ }^{3}$.

Podążając za proponowaną przez Titzmanna metodologią badania epok historycznoliterackich, w celu wyłonienia cezur należy zdecydować się na jakąś figurę retoryczną, której ilościowe i jakościowe aspekty będziemy rozpatrywać, a następnie udzielić odpowiedzi na pytanie, jak zmienia się jej frekwencja w analizowanych tekstach oraz sposób, w jaki jest w nich stosowana. Na przełomy epok będzie wskazywać zmiana ilościowa lub jakościowa figury w różnych punktach chronologicznych.

${ }^{2}$ Ibidem, s. 113.

${ }^{3}$ M. Titzmann, Problemy pojęcia epoki w historii literatury, tłum. K. Jachimczak, „Pamiętnik Literacki” 1988, nr 3, s. 294. 


\section{Syllepsis jako narzędzie periodyzacji}

Ze względu na ograniczającą materiał badawczy rzadkość występowania, ale również na specyficzny charakter pozwalający zarówno na budowanie dramatycznego napięcia, jak i efektu humorystycznego, do eksperymentalnego wdrożenia opisanej metody wybieram syllepsis. Korpus badanych tekstów będzie określony przez występowanie tej figury w polskiej poezji średniowiecza, renesansu, baroku i oświecenia, a zatem epok, których cezury, mimo pewnych kontrowersji, mają w historii literatury utrwalone wyznaczniki. Celem prześledzenia ilościowych i jakościowych różnic w stosowaniu syllepsis będzie sprawdzenie, w jaki sposób dotychczasowe ramy czasowe tych epok pokrywają się z tymi, na które wskazywałaby obserwacja badanej figury.

Heinrich Lausberg w Retoryce literackiej klasyfikuje syllepsis (inaczej: zeugmę złożoną semantycznie) jako jedną z figur tworzonych przez detrakcję, czyli „pominięcie elementów zdaniowych, które normalnie byłyby konieczne”" Jako że syllepsis jest podtypem zeugmy, należy też przywołać definicję tej ostatniej. Jak pisze Lausberg, zeugma to:

Parentetyczna detractio polegająca na opuszczeniu partytywnego (cząstkowego) elementu w wielorakiej koordynacji składników w taki sposób, iż pozostający paralelny element partytywny w obrębie owej koordynacji adaptuje również funkcję pominiętego elementu tak iż pozostającemu składnikowi partytywnemu zostaje nadana nadrzędna funkcja parentetyczna ${ }^{5}$.

W uproszczeniu można przyjąć, że zeugma to figura retoryczna tworzona przez oderwanie jednej bądź kilku części wypowiedzenia, w wyniku czego pozostałe paralelne człony składniowe zostają podporządkowane jednemu członowi nadrzędnemu (najczęściej frazie czasownikowej), tworząc wyrażenie o charakterze eliptycznym.

Syllepsis jest figurą retoryczną powstającą w sposób analogiczny do zeugmy. Podobnie jak zeugma prosta, opiera się zatem na nadrzędności jednego członu względem kilku elementów podrzędnych, połączonych ze sobą syntaktycznie, tyle że tym razem jeden $\mathrm{z}$ tych elementów nie przystaje semantycznie ani do członu nadrzędnego, ani do elementów, z którymi pozostaje w relacji współrzędności. W rezultacie element ten łączy się $\mathrm{z}$ frazą nadrzędną $\mathrm{w}$ sposób tworzący wyrażenie nacechowane metaforycznie. Niezależnie więc od syntaktycznego dopasowania członu nadrzędnego i wszystkich elementów podrzędnych powstaje efekt semantycznego napięcia.

${ }^{4}$ H. Lausberg, Retoryka literacka. Podstawy wiedzy o literaturze, thum. A. Gorzkowski, Bydgoszcz 2002, s. 386.

${ }_{5}^{5}$ Ibidem, s. 388. 
Napięcie to, wytworzone przez sprzężenie elementu dosłownego i metaforycznego, stanowi o unikatowym charakterze tej figury. Zaskakuje ona odbiorcę niecodziennym zestawieniem wyrażeń $\mathrm{z}$ różnych poziomów znaczeniowych, dzięki czemu wyraźnie zaznacza się w utworze, niezależnie od tego, czy jej użycie niesie ze sobą efekt humorystyczny, patetyczny czy pośredni między jednym wariantem a drugim. Pozwala to na jasne rozstrzygnięcie jej obecności w danym tekście, ułatwiające badania ilościowe, jednocześnie otwierając interesujące perspektywy porównawcze w badaniach jakościowych.

Syllepsis jest figurą wyraziście oddziałującą na tekst przez zestawienie dwóch warstw znaczeniowych, dosłownej i metaforycznej, ale stosowaną rzadko. Dla współtwórcy Wielkiej encyklopedii, filozofa i gramatyka Césara Chesneau Dumarsais'go, syllepsis była metaforą klasyfikowaną jako potencjalnie prowadząca do językowej niezręczności ${ }^{6}$. Figurę tę, być może zamiennie z zeugmą, określa się niekiedy jako „formę pokrętnego żartu”"7. Można się zatem spodziewać, zależnie od badanej epoki, zróżnicowanego użycia tejże figury albo unikania jej w wybranych gatunkach literackich. Analiza poszczególnych przykładów może prowadzić do refleksji dotyczącej zarówno samej syllepsis, jak i gatunków, w których występowała.

\section{Średniowiecze}

Datowanie piśmiennictwa w historii literatury polskiej rozpoczyna się wraz ze spisaniem pierwszego dokumentu po łacinie, Dagome iudex. Niedługo potem, w wieku XI, pojawia się hagiografia i poezja ${ }^{8}$. Równolegle do piśmiennictwa łacińskiego rozwijać musiał się przekaz ustny w rodzimym języku, ale dopiero na wiek XV jest datowany pierwszy utwór w całości spisany po polsku9

Próba skonstruowania korpusu średniowiecznych utworów na podstawie kryterium występowania w nich syllepsis prowadzi do znamiennych wniosków. Figury tej nie odnajdziemy w polskojęzycznych tekstach schyłku epoki: antologiach utworów wierszowanych ${ }^{10} \mathrm{i}$ zbiorach poezji sakralnej i świeckiej ${ }^{11}$. Nie należy jednak pochopnie zakładać, że unikanie syllepsis przez ówczesnych autorów mogło wynikać z niskiego poziomu wykształcenia lub ignorancji. Definicja figury

${ }^{6}$ G. Tissol, Appendix B: Syllepsis and Zeugma, w: The Face of Nature: Wit, Narrative, and Cosmic Origins in Ovid's "Metamorphoses", Princeton 1997, s. 219-220.

${ }^{7}$ K. Wales, A Dictionary of Stylistics, Abingdon 2014, s. 385.

${ }^{8}$ T. Michałowska, Literatura polskiego średniowiecza, Warszawa 2011, s. 53-56.

${ }^{9}$ Bogurodzica spisana w roku 1407. Średniowieczna pieśń religijna polska, red. M. Korolko, Wrocław 1980, s. 3-4.

${ }^{10}$ Toć jest dziwne a nowe. Antologia literatury polskiego średniowiecza, red. A. Jelicz, Warszawa 1987.

${ }^{11}$ Średniowieczna poezja polska świecka, red. S. Vrtel-Wierczyński, Kraków 1923. 
była obecna już w gramatykach starożytnych (De figuris z III w. n.e. ${ }^{12}$ przypisywane Herodianowi, Artis gramaticae libri III Diomedesa Gramatyka z IV w. ${ }^{13}$, Ars grammatica Eligiusza Donata z IV w. ${ }^{14}$, De figuris sentetiarum et elocutionis Pseudo-Rufina z IV w. ${ }^{15}$ ), jak i średniowiecznych (Commentum artis Donati [V/VI w.] Pompejusza Gramatyka). Syllepsis zdaje się również nie występować $\mathrm{w}$ poezji tej epoki poza polskim kręgiem kulturowym ${ }^{16}$, także $\mathrm{w}$ poezji łacińskiej ${ }^{17}$, chociaż potwierdzenie tej hipotezy wymagałoby szerzej zakrojonych badań komparatystycznych.

Szczupły korpus zachowanych polskich utworów poetyckich średniowiecza pozwala jedynie na postawienie hipotezy obciążonej ryzykiem błędu. Brak syllepsis w poezji polskiego średniowiecza nie musi być jednak przypadkowy. Zgodnie z myślą św. Augustyna wszelka sztuka powinna być podporządkowana umacnianiu wizji świata, w której odzwierciedleniem władzy boskiej jest władza królewska, a system wasalny stanowi kolejne odbicie tego samego ładu w sferze profanum. W takim porządku świata, który zakłada niezachwiane powielanie wartości i reguł ustanowionych na najwyższym poziomie hierarchicznej drabiny między Bogiem a królem, nie ma miejsca na językową nierozstrzygalność. Każdy podmiot ma przypisane sobie orzeczenie, pozycjonując się także względem przynależnego mu miejsca, przeznaczenia oraz funkcji, wyrażanych pozostałymi częściami mowy. Figurą najlepiej ten ład konsolidującą wydaje się zatem alegoria, a nie syllepsis. Jak zauważa w jednym ze swoich esejów Paul Zumthor:

Czasem znaczenie przenośne przeważa nad dosłownym, czasem znów, szczególnie u wielkich poetów końca średniowiecza, dosłowność przydaje przenośni aspekt tak konkretny i tak dużą siłę wiarygodności, że zanika wszelka idea abstrakcyjna, a alegoria nabiera wartości oryginalnego odkrycia poetyckiego ${ }^{18}$.

${ }^{12}$ Pseudo-Herodian, De figuris, w: Uberlieferungsgeschichte und kritische Ausgabe, red. K. Hajdu, D. Hansen, Berlin 2013, s. 17.

${ }^{13}$ M. Cytowska, Od Aleksandra do Alwara. Gramatyki łacińskie w Polsce w XVI w., Wrocław 1968, s. 71.

${ }^{14}$ Rhetorica Movet. Studies in Historical and Modern Rhetoric in Honour of Heinrich F. Plett, red. P. Oesterreich, T. Sloane, Lejda 1999, s. 79.

${ }^{15}$ Flavius Iosephus, Erasmus Roterodamus, Tyrannius Rufinus, Sigmund Gelen, Jost Amman, Opera Iosephi viri inter Iudaeos doctissimi ac disertissimi, Frankfurt 1580, s. 854.

${ }^{16}$ Die Ritteridee in der deutschen Literatur des Mittelalters: Eine kommentierte Anthologie, red. J. Arentzen, U. Ruberg, Darmstadt 1987; B. Ford, Age of Chaucer: With an Anthology of Medieval Poems, Worthing 1961.

${ }^{17}$ Przykładu syllepsis nie odnajdziemy we wczesnośredniowiecznych hymnach łacińskich ani trzynastowiecznym zbiorze świeckich Carmina Burana. Early latin hymns, red. A. S. Walpole, Cambridge 1922; Carmina Burana - die Lieder der Benediktbeurer Handschrift - zweisprachige Ausgabe, red. B. Bischoff, Monachium 1985.

${ }^{18}$ P. Zumthor, Retoryka średniowieczna, tłum. J. Arnold, „Pamiętnik Literacki” 1977, nr 1, s. 233. 
Syllepsis jest figurą rewidującą znaczenia, pozwalającą na nierozstrzygalność między sensem metaforycznym i dosłownym, a średniowieczny system wartościowania tego typu dowolności nie dopuszczał. Nie wykluczając osobistego aspektu przeżywania sztuki, zawężał jednak stosowane środki w dbałości o to, by sens utworu był ujawniany zgodnie ze światopoglądem autora, a nie przypisywany tekstowi z zewnątrz.

Unikanie syllepsis prawdopodobnie nie wynikało zatem z niewiedzy autorów średniowiecznych, lecz ze świadomego doboru środków odzwierciedlających ówczesny porządek rzeczywistości, podobnie jak to czyniła odwrócona perspektywa malarstwa ikonicznego ${ }^{19}$. Na pierwszy rzut oka porządek obrazu na ikonie może sugerować odbiorcy brak kompetencji autora w zakresie oddawania perspektywy. Tymczasem celem zastosowania perspektywy odwróconej jest postawienie odbiorcy w centrum rzeczywistości oraz przedłożenie alegorycznego znaczenia przypisanego postaciom i gestom nad realizm przedstawienia. Wyraźne kontury średniowiecznych ikon przypominają, że w świecie o jasno wyznaczonym porządku prawda nie może być przedstawiana przez światłocienie. Dlatego właśnie w sztuce średniowiecza nie było miejsca na rozmyte kontury i sylleptyczne napięcie między znaczeniami.

\section{Renesans}

Za początek renesansu w literaturze polskiej przyjmuje się przełom XV i XVI w., postrzegany między innymi jako okres zwrotny w kulturze i literaturze polskiej $^{20}$. Przypada zatem niemal na czas końca tej epoki we Włoszech (rok 1527, data Sacco di Roma ${ }^{21}$ ). Janusz Pelc za „pierwszą i drugą fazę dominacji renesansu" uznaje lata 1510 do 1543 i 1543 do 1565, czyli czas działalności poetów nowołacińskich oraz pierwszych poetów polskich. Lata 1565-1590 określa jako odrodzeniowe „apogeum”. Jest to okres rozwoju twórczości polskojęzycznej i rozkwitu twórczości Kochanowskiego ${ }^{22}$. Jednak w tym samym czasie tworzy Mikołaj Sęp Szarzyński, którego twórczość zaliczana jest już do epoki baroku²3.

Humanistyczny zwrot w stronę wcześniej pomijanych aspektów poezji greckiej i rzymskiej pozwolił na ponowne odnalezienie niegdyś bardziej popularnych środków wyrazu, takich jak zeugma złożona semantycznie. Ze względu jednak

${ }^{19}$ B. Uspienski, Strukturalna wspólnota różnych rodzajów sztuki, Ogólne zasady organizacji dzieła malarskiego i literackiego, w: idem, Poetyka kompozycji, tłum. P. Fast, Katowice 1997, s. 192-223.

${ }^{20}$ K. Budzyk, J. Dürr-Durski, Stan badań i potrzeby nauki o literaturze okresu kontrreformacji, Warszawa 1951, s. 126-134.

${ }^{21}$ J. Burckhardt, Kultura odrodzenia we Wtoszech, Warszawa 1961, s. 28-30.

22 J. Pelc, Literatura renesansu w Polsce, Warszawa 1994, s. 184-222.

${ }^{23}$ M. Markiewicz, Historia Polski, 1492-1795, Kraków 2002, s. 264. 
na renesansowe dążenie do harmonii, tak charakterystyczna figura jak syllepsis, przerywająca tok wypowiedzi w sposób mający wywrzeć silne wrażenie na odbiorcy, wciąż była używana dość rzadko, z dużą dozą ostrożności.

Dokonując przeglądu wierszy autorów z pogranicza średniowiecza i renesansu, możemy dojść do wniosku, że syllepsis raczej w ich twórczości nie występowała, ewentualnie bardzo rzadko. U Biernata z Lublina nie ma jej wcale (1465-1529) ${ }^{24}$. Zeugma złożona syntaktycznie pojawia się u Mikołaja Reja (1505-1569) „Jużechmy spłacili długi, / Mamy tam pana i sługi”25; „Wszytko na stronę odłożyć, / Strach, miłość i powinności” ${ }^{26}$ ). W liczącej ponad dwa tysiące wersów Krótkiej rozprawie między trzemi osobami, Panem, Wójtem a Plebanem można dopatrzyć się - jednego tylko - przykładu, w którym zachodzi sprzężenie między wyrażeniem dosłownym (tracić pieniądze) i metaforycznym (tracić zdrowie):

Każdy to sowito płaci,

Zdrowie i pieniądze traci.

Metafora „utraty zdrowia” jest w języku dobrze zakorzeniona, co niweluje wrażenie dysonansu, nie burząc harmonii tekstu. Cytowany dwuwers zachowuje jednocześnie humorystyczne nacechowanie, jakie może wprowadzać syllepsis.

$\mathrm{Na}$ częstotliwość pojawiania się w utworach renesansowych figur, których celowo unikali autorzy średniowieczni, pewien wpływ mógł mieć rozwój poezji polsko-łacińskiej, inspirującej się dorobkiem autorów starożytnych ${ }^{27}$. Trzeba jednak powiedzieć, że zmiana tematyki poezji, a nawet rozwój twórczości pisanej w języku polskim nie znajdowały natychmiastowego przełożenia na reformy zasad kompozycyjnych. Renesansowe podręczniki retoryczne wykazywały wprawdzie tendencję do wyodrębniania syllepsis (jako zjawiska będącego rodzajem zeugmy ${ }^{28}$ ), lecz precyzyjne kompozycje renesansu oparte na wierze w harmonię wszechświata skłaniały jednocześnie do wystrzegania się środków wywołujących u odbiorcy zaskoczenie i zaburzających równowagę tekstu przez semantyczną nierozstrzygalność ${ }^{29}$. Nie dziwi zatem, że nieco wyższa frekwencja zeugmy i syllepsis pojawiła się dopiero w twórczości poetów okresu późniejszego,

${ }^{24}$ Biernat z Lublina, Bajki, red. K. Sokulska, Wrocław 1998; idem, Ezop, red. J. Gruchała, Kraków 1997.

${ }^{25}$ Antologia bajki polskiej. Mikołaj Rej, red. J. Ejsmond, Warszawa 1915, s. 89.

${ }^{26}$ Ibidem, s. 119.

${ }^{27}$ Przykłady sporadycznie pojawiającej się syllepsis możemy odnaleźć u Filipa Kallimacha (1437-1496), Jana Dantyszka (1485-1548) i Andrzeja Krzyckiego (1482-1537). Antologia poezji polsko-łacińskiej 1470-1543, red. A. Jelicz, Szczecin 1956.

${ }^{28}$ P. Mack, Elizabethan Rhetoric: Theory and Practice, Cambridge 2009, s. 82-100.

${ }^{29}$ Koncepcja poetyki wyrażona m.in. we wpływowym Poetices libri VII Ceasara Scaligera. C. Segre, Poetyka, „Pamiętnik Literacki” 1987, nr 1, s. 260-274. 
jak na przykład w sielankach Szymona Szymonowica (1558-1629 - „Za tym spokojne życie i wszystko się wiedzie”,30 , „Którzy piszczałkę i rym uczony miłują"31).

Nieco wcześniej niezwykłą dojrzałość w zastosowaniu syllepsis uzyskał Jan Kochanowski (1530-1584). Występowała nie tylko w utworach o charakterze lekkim i humorystycznym („Bo dobre mienie, / Perły, kamienie, / Także wiek młody / I dar urody, / Mieśca wysokie, / Władze szerokie / Dobre są”32; „Tak między nieprzyjacioły / Upad niesie i dar goły"33), lecz także w Trenach. W tych ostatnich syllepsis sprzyjała wyjaskrawieniu głębokiej dysharmonii, by następnie, w Trenie VII i Trenie XVI, wyrazić rozpacz niepozwalającą na postrzeganie świata jako zgodnej całości, w której naturalnym dopełnieniem ziemskiego życia jest śmierć. Do najsilniej zarysowanych przykładów należą tu zakończenie pierwszej strofy Trenu XVI („Lutnią i wdzięczny rym porzucić muszę. / Ledwe nie duszę"34) oraz pełne goryczy wykrzyknienie zamykające Tren VII („Niestetyż, i posag, i ona / W jednej skrzynce zamkniona!"35). W pierwszym przykładzie, w którym dosłowne porzucenie „lutni” towarzyszy metaforycznemu porzuceniu „rymu”, oba te komponenty, balansując na granicy dosłowności (porzucić lutnię dosłownie, czyli odstawić przedmiot i go nie używać) i metaforyczności (porzucić rym, czyli zaniechać dalszej twórczości), zostają dodatkowo zestawione $\mathrm{z}$ „porzuceniem duszy”, a więc - z silnie kontrastującym, spiętrzającym się w intensywności wyrazu, określeniem beznadziejności dalszego egzystowania. Kochanowski przechodzi gwałtownie od rezygnacji z tworzenia do utraty zaufania w stabilność własnego bytu. Syllepsis nie wywołuje w tym wypadku efektu zaskoczenia, ale pomaga w odzwierciedleniu skrajnej apatii i braku sił odczuwanego przez zrozpaczony podmiot liryczny.

Zabiegiem wywołującym zaskoczenie odbiorcy jest zestawienie ,[...] posag i ona / W jednej skrzynce zamkniona”. Napięcie zbudowane jest na groteskowej przepaści między obrazem rzeczy zmarłej dosłownie schowanych w skrzyni i ułożonych w trumnie zwłok. Nagłe przejście między jednym a drugim przywodzi na myśl naturalne poczucie niepokoju, jakie wywołuje u człowieka widok zmarłego ciała, przez śmierć nagle zamienionego w przedmiot, statycznego i pozbawionego życia. Tak jakby doczesne szczątki same zawierały w sobie sylleptyczną podwójność - będąc jednocześnie obiektem nieożywionym i pozostałością po osobie, którą jednocześnie są i do której już nie należą.

${ }^{30}$ S. Szymonowic, Żeńcy, w: idem, Sielanki, red. J. Łoś, Kraków 1921, s. 110.

${ }^{31}$ Ibidem, s. 118.

32 J. Kochanowski, Na zdrowie, w: idem, Dzieła polskie, t. 1, red. J. Lorentowicz, Warszawa 1919, s. 349.

${ }^{33}$ Idem, O Hektorze, w: ibidem, s. 295.

${ }^{34}$ Idem, Tren XVI, w: ibidem, s. 65.

${ }^{35}$ Idem, Tren VII, w: ibidem, s. 45. 
Głównym wyjątkiem od renesansowej zasady harmonii pozostają teksty o charakterze humorystycznym. Dobrze zdaje się to wyjaśniać renesansowy słownik retoryki Henry'ego Peachama, Ogród elokwencji, aforystycznie puentując definicję syllepsis: „Ta figura [...] wzbudza po wielekroć najprzyjemniejszy rodzaj jowialnej wesołości”" ${ }^{36}$. Jako exemplum przypominają się tu słowa z fraszki Dantyszka: „Po trzech dniach często ryby - a i gość - zaśmierdnie”37. Przykład ten pokazuje, że renesans niewątpliwe znał możliwości tkwiące w zastosowaniu figury syllepsis. Było to jednak zjawisko marginalne, wiążące się z gatunkami lekkimi. Kochanowski w Trenach pozwolił sobie na wyłamanie się z ogólnych tendencji epoki, ze środka renesansu zapowiadając już poetykę autorów barokowych tak, aby w syllepsis wyrażały się paradoksy przeżycia metafizycznego i chęć odzwierciedlenia czysto ludzkiego aspektu cierpienia.

\section{Barok}

Dopiero barok, z całą swoją ostentacją i nieregularnością, pozwolił syllepsis na przeżycie rozkwitu. Jego początek, przypadający na koniec XVI w., pokrywa się ze schyłkiem renesansu. Figura - dotychczas dość trudna (renesans), czy wręcz niemożliwa (średniowiecze) do wytropienia w tekstach poprzednich epok - w drugiej fazie baroku nagle staje się łatwo odnajdywalna ${ }^{38}$.

W dziełach poetyckich cechą charakterystyczną tej epoki jest zarówno mnogość nagromadzonych figur retorycznych, jak i sposób, w jaki są one stosowane. Esej Morrisa Crolla pod tytułem „Styl barokowy w prozie” mówi wręcz o retoryczności tego okresu. Dominacja dispositio stała się nawet swoistym wyznacznikiem pozwalającym Crollowi wskazać linię demarkacyjną oddzielającą teksty barokowe od niebarokowych ${ }^{39}$.

Croll definiuje „frazę barokową” przez kontrast z uprzednio obowiązującą „cycerońską" strukturą dzieła szesnastowiecznego, opisową i pełną harmonii. Badacz wskazuje na cztery innowacyjne cechy nowego stylu: zwięzłość, podniosłość, asymetrię i unikanie prostoty związków syntaktycznych ${ }^{40}$. Syllepsis jest figurą kunsztowną, komasującą tekst dzięki zastosowaniu elipsy, spełnia więc wymogi treściwości i unikania prostoty, jakie przed klasyfikacją tekstu jako barokowego stawia Croll. Współgrając z cechami frazy barokowej, syllepsis

${ }^{36}$ „This figure as it uniteth two words of one sounde, so it distinguisheth them asunder by the diversitie of their sence, wherby it moveth many times a most pleasent kind of civile mirth". H. Peacham, The Garden of eloquence, red. W. R. Espy, New York 1983, s. 58.

${ }^{37}$ Antologia poezji polsko-łacińskiej 1470-1543, s. 113.

${ }^{38}$ Mariusz Markiewicz wyróżnia trzy fazy baroku: pierwszą, przypadającą na panowanie Zygmunta III Wazy, fazę panowania baroku, kończącą się na przełomie XVII i XVIII w. oraz fazę schyłkową w czasach saskich. M. Markiewicz, op. cit., s. 278-284.

${ }^{39}$ M. W. Croll, Baroque prose style: The Anti-Ciceronian Movement, New Jersey 1970, s. 21-24.

${ }^{40}$ Ibidem, s. 36-42. 
odzwierciedla ducha całej epoki, której teksty „naśladują chaotyczną naturę świata stając się hermetyczną hybrydą form i stylów" ${ }^{41}$.

Jeśli przyjrzymy się twórczości przełomu renesansu i baroku - Sebastiana Grabowieckiego (1543-1607), Stanisława Grochowskiego (1542-1612) i Kaspra Miaskowskiego (1549-1622) - po raz kolejny możemy zaobserwować, jak zmiana w wykorzystywaniu dostępnych figur retorycznych podążą za ewolucją tematyki utworów, a nie odwrotnie. U wszystkich wspomnianych autorów spotkać możemy się z zeugmami złożonymi syntaktycznie, ale nieczęsto możemy natrafić na kontrast semantyczny, a jeśli nawet, to nie kłóci się on z zasadą zachowania harmonii, wykorzystując jedynie zbliżone do siebie znaczeniowo zestawiania dosłownych i metaforycznych wyrażeń („Obacz me serce i żałości” ${ }^{42}$, „Racz sprawami i ustami / Memi zawsze kierować”43). Wyjątek mogą stanowić „Proporce, wojny i pary złączone" u Kaspra Miaskowskiego ${ }^{44}$, jednakże zważając na wspomniane wcześniej prekursorskie zastosowanie syllepsis przez poetę z Czarnolasu, wystąpienie tak wyraźnego przykładu w utworze zatytułowanym Lutnia Jana Kochanowskiego wielkiego poety polskiego zyskuje dodatkowe znaczenie. Podobnych przykładów będzie znacząco przybywać wraz z trwaniem nowej epoki.

Znamiennym przykładem barokowego użycia syllepsis i częstości, z jaką była ta figura wówczas stosowana, może być sonet Do galerników z Lutni Jana Andrzeja Morsztyna:

Strapieni ludzie, źle się z wami dzieje,

Lecz miłość ze mną okrutniej poczyna:

Was człowiek, a mnie silny bóg zacina,

Wy macie wyniść, jam bez tej nadzieje.

Was spólne słońce, mnie własny jad grzeje,

Was pręt od grzbieta, mnie z serca zacina,

Wam nogi łańcuch, a mnie szyję zgina,

Wam ręka tylko, a mnie dusza mdleje.

Was wiatr, a mnie ból ciska na przemiany,

Was prawo, mnie gwałt trzyma w tym więzieniu,

Wam podczas sternik sfolguje zbłagany,

${ }^{41}$ A. Nowicka-Jeżowa, Uwagi o heterogeniczności literatury barokowej. Gtos $w$ dyskusji, w: Literatura a heterogeniczność kultury. Poetyka i obraz świata, red. E. Czaplejewicz, E. Kasperski, Warszawa 1996, s. 186-191.

${ }^{42}$ S. Grabowiecki, CXI, w: Sebastiana Grabowieckiego Rymy duchowne, red. J. Korzeniowski, Kraków 1893, s. 135.

${ }^{43}$ „Omni die dic Mariae...” w przekładzie Stanisława Grochowskiego, w: S. Grochowski, Wiersze i insze pisma co przebrańsze, częścia z łacińskich przełożone, częścią od niego samego napisane, Kraków 1607, s. 148-153.

${ }^{44}$ K. Miaskowski, Zbiór rytmów, red. A. Karpiński, Wrocław 1995, s. 275. 
Ja darmo czekam ulgi w uciążeniu.

A w tym jest mój stan nad wasz niewytrwany,

Że wy na wodzie, ja cierpię w płomieniu ${ }^{45}$.

Każda ze strof utworu zawiera w sobie syllepsis: „zacina” - prętem „Was człowiek, a mnie i silny bóg”, „grzeje” - „Was spólne słońce, mnie i własny jad”, ponownie „zacina” - „Was pręt od grzbieta, mnie z serca”, „mdleje” - „Wam ręka tylko, a mnie i dusza”, „ciska” - „Was wiatr, a mnie i ból”, „trzyma w tym więzieniu” - „Was prawo, mnie i gwałt”, „wy cierpienie na wodzie, ja cierpię i w płomieniu". Siedem zastosowań w jednym utworze tej, rzadkiej skądinąd, figury retorycznej buduje silną kontrastowość wiersza.

To tylko jeden z przykładów wykorzystania syllepsis do opisu mistycznej walki wewnętrznej i tego, jak różni się ona od codziennego, fizycznego trudu. Można by jednak przytoczyć wiele innych exemplów. Sonet IV Mikołaja Sępa Szarzyńskiego zawiera tę figurę już w samym tytule: „O wojnie naszej, którą wiedziemy z szatanem, światem i ciałem”. Pojawia się ona też w podobnym kontekście w Vanitas Vanitatum Hieronima Morsztyna:

Noc i dzień prędko bieży a śmierć następuje,

Za tą ostatni termin; niech się kto chce czuje,

Świat, szatan, własne ciało bitwę z człekiem wiedzie,

A jakoż tu nie upaść? Któż przezpieczen będzie? ${ }^{46}$

Zarówno tytuł sonetu Sępa Szarzyńskiego, jak i strofa z Morsztyna przypominają refleksję św. Jana od Krzyża, odzwierciedlając myśl podobną do wyrażonej w jednym z jego najważniejszych dzieł, Nocy ciemnej, opisującej podróż duszy z jej cielesnej powłoki, z którą nie jest tożsama, aż przed oblicze Boga. Powtarzalność wątku opisującego drogę do duchowej doskonałości w różnych formach poezji barokowej pozwala jednakże dostrzec, w jaki sposób syllepsis staje się narzędziem jego kontemplacji. Podobnie jak u Kochanowskiego, wyraża ona doświadczenie trudne i dogłębnie ludzkie, zwracając się w stronę metafizycznego wymiaru doczesnego cierpienia.

\section{Oświecenie}

Pierwszą pełną definicję syllepsis zawdzięczamy dopiero oświeceniu. Co ciekawe, definicja ta negatywnie wartościuje badaną figurę. Dla współtwórcy Wielkiej encyklopedii, filozofa i gramatyka, Césara Chesneau Dumarsais'go, syllepsis była

${ }^{45}$ J. A. Morsztyn, Do galerników, w: idem, Lutnia, Kraków 2002, s. 107.

${ }^{46}$ H. Morsztyn, Vanitas Vanitatum, w: Antologia polskiej poezji metafizycznej epoki baroku: od Mikołaja Sępa Szarzyńskiego do Stanistawa Herakliusza Lubomirskiego, red. K. Mrowcewicz, Warszawa 2005, s. 49. 
rodzajem nieprawidłowej metafory, klasyfikowanym w charakterze konstrukcji prowadzącej potencjalnie do językowej niezręczności ${ }^{47}$. Figurę tę określał jako formę pokrętnego żartu. Skoro zaś syllepsis miała prowadzić do błędu, nietrudno zgadnąć, że twórcy tego okresu jej unikali. I rzeczywiście, zawartej w Wielkiej encyklopedii krytyce zdaje się wtórować znikoma - szczególnie w porównaniu $\mathrm{z}$ barokiem - frekwencja figury w poezji oświeceniowej. Proces ten rozpoczął się już w schyłkowej fazie baroku przypadającej na czasy saskie ${ }^{48}$. Józef Baka, który sięgał po liczne zeugmy, krótkie frazy sprzęgające ze sobą pokrewne znaczeniowo słowa (np. pochodzące z tego samego utworu: „tortury i kołowroty”; „łotr i tyran”; „plaga i kara" ${ }^{49}$ ), samą syllepsis stosował niezwykle rzadko (przykład wyjątku od reguły: „Ryczałtem i gwałtem / W grób spieszą"50). Wraz z towarzyszącym tym czasom chaosem zdaje się rozpadać również sam styl języka. W kolejnych dziesięcioleciach zainteresowanie syllepsis zmniejszyło się jeszcze bardziej, a autorzy oświecenia, podobnie jak w renesansie, pozwalali sobie na używanie jej jedynie w utworach o charakterze humorystycznym, jak na przykład w jednej z bajek Krasickiego („Wszystko to odmienne: / Łaska pańska, gust kobiet, pogody jesienne" ${ }^{\text {") }}$ ) czy też Pieśni Ciarlatańskiej na Jarmarku Adama Naruszewicza („Sędzia ma czyste ręce od łez i mamony”52).

Oświecenie wydało nie tylko pejoratywną ocenę figury, która w baroku przeżyła swój rozkwit, lecz także przekreśliło w ślad za tym wyrażające się w syllepsis cechy barokowej refleksji, wykluczając wieloznaczność i mistyczne doświadczenie niedookreślenia rzeczywistości, która łączy w sobie warstwę materialną i duchową. Unikanie syllepsis było więc ilustracją programu kształtowania poezji w opozycji do epoki poprzedniej, tak jakby dało się ją wymazać i powrócić na nowo do humanistycznych gustów i wątków renesansu.

\section{Wnioski}

Syllepsis, wprowadzając chaos przez niejednoznaczność i zachwianie semantyczne między dwoma sprzęgniętymi ze sobą członami zdania, jednocześnie łączy je ze sobą w nową, spójną całość. $Z$ tego powodu figura największym zainteresowaniem cieszyła się w okresie baroku. Gdyby wybrać losowo 50 utworów zarówno z tej epoki, jak i z epok sąsiadujących, będzie to widoczne jeszcze wyraźniej. W próbce 50 dzieł renesansowych, którą eksperymentalnie wybrano

${ }^{47}$ G. Tissol, Appendix B: Syllepsis and Zeugma, s. 219-220.

${ }^{48}$ Od pierwszej połowy XVIII w. M. Markiewicz, op. cit., s. 280-284.

${ }^{49}$ J. Baka, Uwaga kary niezliczonej grzechów, w: idem, Uwagi rzeczy ostatecznych i złości grzechowej, Warszawa 1828, s. 91.

${ }^{50}$ J. Baka, Uwaga zabawnym czy zatrudnionym chmielem głowom, w: ibidem, s. 79.

${ }^{51}$ I. Krasicki, Abuzaj i Tair, w: idem, Poezje, t. 1, Paryż 1830, s. 4.

${ }^{52}$ A. Naruszewicz, Wybór poezji, Warszawa 1882. 
na potrzeby niniejszego artykułu ${ }^{53}$ syllepsis pojawia się łącznie siedem razy, u poetów barokowych ${ }^{54}-19$, a w tekstach oświeceniowych zaledwie czterokrotnie $^{55}$. Częstotliwość jej występowania może służyć za jeden z parametrów wyznaczających granice okresu historycznoliterackiego, w sposób podobny do tego, jak cechy obrazu w malarstwie są jednocześnie konsekwencją i znakiem przemiany myślowej zachodzącej na pograniczu następujących po sobie dominujących stylów.

Dokonując przeglądu poezji średniowiecznej, renesansowej, barokowej i oświeceniowej, teoretycznie ograniczamy się do potwierdzenia utartych cezur, wskazując na zgodność obrazu wynikającego z frekwencji syllepsis z ogólnymi tendencjami myślowymi epoki. Nową obserwacją jest jednak dostrzeżenie pewnego opóźnienia w stosowaniu figury w stosunku do przemian tematycznych epoki. Syllepsis, unikana w średniowieczu, nie występuje również we wczesnym renesansie i równie oszczędnie, jak w dojrzałym renesansie, dawkowana jest na początku baroku. Zmiana topiki nie jest więc konsekwencją wynikającą z potencjału nowych środków stylistycznych, lecz odwrotnie - to styl dojrzewa wraz z przemianami myślowymi epoki, przesuwając w czasie cezury wynikające z badań (jakościowych i ilościowych) nad figurami retorycznymi w stosunku do kryterium opartego na watkach ideowych.

Śledzenie tego, jak funkcjonuje figura retoryczna w sensie jakościowym, może też prowadzić do odkrycia zaskakujących wyjątków. Zupełnym wyłamaniem się z renesansowej zasady harmonii jest sposób użycia syllepsis w Trenach, dzięki czemu Kochanowski okazuje się prekursorem barokowego stylu kontemplacji śmiertelności ciała, zarazem oddając nowatorsko intymne przeżycie związane z osobistym cierpieniem i rozpaczą, nieprzystające do renesansowej koncepcji ładu.

Figura retoryczna nie może zatem służyć za wyłączne narzędzie do wyznaczania historycznoliterackich cezur. Dopiero zderzenie „narracyjnej” bądź też „deskryptywnej” historii literatury, jak ją określa Titzmann, z proponowaną przez niego równoległą historią struktur literackich, przynosi zniuansowany obraz przekształceń między epokami.

${ }^{53} 50$ utworów renesansowych z uwzględnieniem 10 utworów: Filipa Kallimacha (2 syllepsis), Konrada Celtisa (1 syllepsis), Andrzeja Krzyckiego (3 syllepsis), Jana Dantyszka (1 syllepsis), Klemensa Janicjusz (0 syllepsis).

${ }^{54} 50$ utworów barokowych z uwzględnieniem 10 utworów: Mikołaja Sępa Szarzyńskiego (4 syllepsis), Jana Andrzeja Morsztyna (9 syllepsis), Daniela Naborowskiego (2 syllepsis), Stanisława Herakliusza Lubomirskiego (2 syllepsis), Hieronima Morsztyna (2 syllepsis).

5550 utworów oświeceniowych z uwzględnieniem 10 utworów: Ignacego Potockiego (0 syllepsis), Franciszka Karpińskiego (0 syllepsis), Franciszka Kniaźnina (0 syllepsis), Adama Naruszewicza (1 syllepsis), Stanisława Trembeckiego (1 syllepsis). 


\section{Bibliografia}

Antologia bajki polskiej. Mikołaj Rej, red. J. Ejsmond, Warszawa 1915. Antologia poezji polsko-łacińskiej 1470-1543, red. A. Jelicz, Szczecin 1956. Antologia polskiej poezji metafizycznej epoki baroku: od Mikołaja Sępa Szarzyńskiego do Stanisława Herakliusza Lubomirskiego, red. K. Mrowcewicz, Warszawa 2005.

Baka, Józef, Uwagi rzeczy ostatecznych i złości grzechowej, Warszawa 1828.

Biernat z Lublina, Bajki, red. K. Sokulska, Wrocław 1998.

Biernat z Lublina, Ezop, red. J. Gruchała, Kraków 1997.

Budzyk, Kazimierz, Dürr-Durski, Jan, Stan badań i potrzeby nauki o literaturze okresu kontrreformacji, Warszawa 1951.

Burckhardt, Jacob, Kultura odrodzenia we Włoszech, Warszawa 1961.

Croll, Morris W., Baroque prose style: The Anti-Ciceronian Movement, New Jersey 1970.

Cytowska, Maria, Od Aleksandra do Alwara. Gramatyki łacińskie w Polsce w XVI w., Wrocław 1968.

Flavius Iosephus, Erasmus Roterodamus, Tyrannius Rufinus, Sigmund Gelen, Jost Amman, Opera Iosephi viri inter Iudaeos doctissimi ac disertissimi, Frankfurt 1580; Katalog książek Google, https://books.google.pl/books?id=fG7U-t19YNUC\&lpg= PA542 (d.d. 9.01.2019).

Grammatici Graeci, red. A. Lentz, G. Uhling, Pensylwania 1965.

Grochowski, Stanisław, Wiersze i insze pisma co przebrańsze, częścia z łacińskich przełożone, częścią od niego samego napisane, Kraków 1607.

Kochanowski, Jan, Dzieła polskie, red. J. Lorentowicz, Warszawa 1919.

Krasicki, Ignacy, Poezje, t. 1, Paryż 1830.

Lausberg, Heinrich, Retoryka literacka. Podstawy wiedzy o literaturze, tłum. A. Gorzkowski, Bydgoszcz 2002.

Mack, Peter, Elizabethan Rhetoric: Theory and Practice, Cambridge 2009.

Miaskowski, Kasper, Zbiór rytmów, red. A. Karpiński, Wrocław 1995.

Michałowska, Teresa, Literatura polskiego średniowiecza, Warszawa 2011.

Morsztyn, Jan Andrzej, Lutnia, Kraków 2002.

Naruszewicz, Adam, Wybór poezji, Warszawa 1882.

Nowicka-Jeżowa, Alina, Uwagi o heterogeniczności literatury barokowej. Głos w dyskusji, w: Literatura a heterogeniczność kultury. Poetyka i obraz świata, red. E. Czaplejewicz, E. Kasperski, Warszawa 1996.

Peacham, Henry, The Garden of eloquence, red. W. R. Espy, New York 1983.

Pelc, Janusz, Literatura renesansu w Polsce, Warszawa 1994.

Rhetorica Movet. Studies in Historical and Modern Rhetoric in Honour of Heinrich F. Plett, red. P. Oesterreich, T. Sloane, Lejda 1999.

Sebastiana Grabowieckiego Rymy duchowne, red. J. Korzeniowski, Kraków 1893.

Segre, Cesare, Poetyka, „Pamiętnik Literacki” 1987, nr 1.

Szymonowic, Szymon, Sielanki, red. J. Łoś, Kraków 1921.

Średniowieczna pieśń religijna polska, red. M. Korolko, Wrocław 1980.

Średniowieczna poezja polska świecka, red. S. Vrtel-Wierczyński, Kraków 1923. 
Tissol, Garth, The Face of Nature: Wit, Narrative, and Cosmic Origins in Ovid's "Metamorphoses", Princeton 1997.

Titzmann, Michael, Probleme des Epochenbegriffs in der Literaturgeschichtsschreibung, Konstanz 1967.

Titzmann, Michael, Problemy pojęcia epoki w historii literatury, tłum. K. Jachimczak, „Pamiętnik Literacki” 1988, nr 3.

Toć jest dziwne a nowe. Antologia literatury polskiego średniowiecza, red. A. Jelicz, Warszawa 1987.

Uberlieferungsgeschichte und kritische Ausgabe, red. K. Hajdu, D. Hansen, Berlin 2013. Uspienski, Boris, Poetyka kompozycji, tłum. P. Fast, Katowice 1997.

Zumthor, Paul, Retoryka średniowieczna, tłum. J. Arnold, „Pamiętnik Literacki” 1977, nr 1.

AlEKSANDRA SiERMińSKA - bada historię retoryki i jej potencjalną użyteczność we współczesnej refleksji literaturoznawczej. Amatorsko fascynuje się historią sztuki, w tym również warstwą znaczeniową obiektów architektonicznych. Jest doktorantką Szkoły Doktorskiej Nauk Humanistycznych na Uniwersytecie Warszawskim. 